\title{
Os males do Brasil são: a doença como elemento distintivo da condição de ser brasileiro
}

\author{
Ermelinda Maria Araújo Ferreira ${ }^{1}$
}

\begin{abstract}
A saúde como literatura, como escrita, consiste em inventar um povo que falta... A literatura é delírio $e$, a esse título, seu destino se decide entre dois polos do delírio. O delírio é uma doença, a doença por excelência a cada vez que erige uma raça pretensamente pura e dominante. Mas ele é a medida da saúde quando invoca essa raça bastarda oprimida que não para de agitar-se sob as dominações, de resistir a tudo o que esmaga e aprisiona e de, como processo, abrir um sulco para si na literatura... Fim último da literatura: pôr em evidência no delírio essa criação de uma saúde, ou essa invenção de um povo, isto é, uma possibilidade de vida. Escrever por esse povo que falta... ("por" significa "em intenção de" e não "em lugar de".)
\end{abstract}

Gilles Deleuze

A Virgem vai pelo caminho

Visitar Jesus, e Jesus perguntou:

O que é aquilo?

- E a Virgem the respondeu:

- O inferno que vós salvais!

- Com que se curaria?

- Com o unto de porco e pó da guia.

- Em honra de Deus e da Virgem Maria.

Espólio de medicina popular portuguesa, recolhido por Michel Giacometti

Eu insulto o burguês-funesto!

O indigesto feijão com toucinho, dono das tradições!

Fora os que algarismam os amanhãs!

Olha a vida dos nossos setembros!

Fará sol? Choverá? Arlequinal!

Mas as chuvas dos rosais

O êxtase fará sempre Sol!

Mário de Andrade

\footnotetext{
${ }^{1}$ Doutora em letras e professora do Programa de Pós-Graduação em Letras da Universidade Federal de Pernambuco (UFPE), Recife, PE, Brasil. E-mail: ermelindaferreir@uol.com.br
} 
Este ensaio nasceu da intenção de comparar as recolhas de dados sobre a medicina empírico-tradicional em Portugal e no Brasil, por iniciativa de dois etnomusicólogos: Michel Giacometti (Córsega, 1929, e Faro, 1990), naturalizado português, cujo acervo, recentemente descoberto, foi reunido no volume Artes de cura e espanta-males (2009); e o brasileiro Mário de Andrade (São Paulo, 1893-1945), autor do livro Namoros com a medicina (1937), que contém dois artigos, "Terapêutica musical" e "A medicina dos excretos". A similaridade desses trabalhos aponta para o interesse de ambos os pesquisadores pela cultura popular - em particular aquela relacionada ao entendimento espontâneo do povo luso-brasileiro sobre os males do corpo e da alma, e de suas estratégias instintivas, analógicas e/ou empíricas de tratamento e de cura -, instigando o leitor à verificação dos processos de transferência das tradições fomentadas no ideário lusitano antigo, perpetuadas no Brasil rural e no Brasil urbano não beneficiário das conquistas da medicina científica moderna.

A comparação entre os livros - elaborados em torno dos fichamentos exaustivos de seus autores sobre as definições populares de doenças e de práticas terapêuticas em sua maioria marcadas por influências do imaginário europeu medieval, enriquecidas na colônia pela contribuição dos hábitos das culturas indígena e africana revelou-se difícil por se tratar, em grande parte, de enumerações de sintomas relacionados ao mau funcionamento dos diversos sistemas fisiológicos, e das mezinhas, práticas, ditos e crendices associados pelo povo ao restabelecimento do equilíbrio e do bem-estar do organismo comprometido por esta ou aquela razão. Embora muitas vezes curiosos, a mera explanação desses relatos seria pouco relevante para nós, se resultasse apenas num comentário sobre as peculiaridades e excentricidades dessa medicina.

A exploração do tema por sua vertente histórica também nos seduziu, mas encontramo-la já primorosamente desenvolvida, entre outros, no excelente ensaio do médico e escritor Pedro Nava, "Introdução ao estudo da História da Medicina Popular no Brasil" (2003), que nos apresenta, minuciosamente, os fundamentos culturais da medicina popular brasileira desde a sua influência portuguesa, a partir de considerações sobre as obras de Frei Manoel de Azevedo, Fonseca Henriques, Curvo Semedo e Bernardo Pereyra. Diz Nava que: 
A medicina popular do português, transportada pelo navegador, pelo degredado, pelo soldado e pelo colono, aqui iria ser o elemento mais forte e dominante da nossa arte curativa popular. Essa influência sente-se até hoje - pura e quase livre de deformações na sua transmissão escrita e interpolada de contribuições indígenas e negras, no espírito com que é ministrada pelos nossos curandeiros e recebida pelos pacientes (Nava, 2003, p. 171).

É notória a relevância dada pelo médico à importância da religiosidade sempre presente no desenvolvimento da medicina portuguesa, pois, "quanto mais um grupo cultiva os seus sentimentos de solidariedade, tanto mais numerosos serão os meios por que ela se manifestará e, portanto, mais ricas e cheias de recursos a sua medicina douta e popular. Um povo cruel, rude ou indiferente nunca poderá ter uma Arte superior" (Nava, 2003, p. 172), diz ele, assinalando que:

À medida que se lhe firmava o pensamento cristão, ao influxo do apostolado exercido em sua terra, desde o século XIII, pelos monges e frades cistercienses, dominicanos e franciscanos, multiplicavam-se na mesma os lazaretos, as corporações de "mesteres", as confrarias, os hospitais, e depois as Misericórdias - por intermédio das quais eram praticadas a caridade e a fraternidade no sentido evangélico. Dentro destas casas progrediria a medicina erudita do país, ela também inseparável, nos seus melhoramentos, dos princípios éticos inspiradores dos médicos. $\mathrm{E}$ ao lado destas casas da bondade coletiva, ao lado do surto da medicina oficial nelas radicado - criavase, à base da bondade de cada um, o imenso arsenal de conhecimentos sintomáticos, de tratamentos empíricos e sobrenaturais de que a medicina popular portuguesa é um dos exemplos mais extraordinários (Nava, 2003, p. 172).

Boa parte do trabalho de Pedro Nava é dedicado à análise da "medicina expiatória e imunda", coincidindo com a natureza das recolhas feitas por Michel Giacometti em Portugal e por Mário de Andrade no Brasil. Essas recolhas assinalam, no remédio estercorário popular, o entendimento da doença como um castigo, de onde advém a ideia da penitência e da expiação como base da cura. A prodigiosa quantidade de imundícies que entram em certas fórmulas da farmacopeia portuguesa - urina, saliva, fezes humanas e de animais, cabelos, unhas e ossos, anotadas nas mais de cinco mil fichas recolhidas por Giacometti - tem ascendência muito legítima no emprego que o selvagem fazia da banha de cobra, de jacaré, do cuspe, da urina e do 
esmegma, e no que o africano fazia de numerosas peçonhas e porcarias de origem animal, anotadas por Mário de Andrade e discutidas por Pedro Nava. Para o médico, esse conjunto de conhecimentos rudimentares deve ser encarado como um fenômeno extraordinariamente complexo, de vivo interesse para o sociólogo, o etnólogo e o sanitarista.

\section{A doença como metáfora}

A medicina de base natural, a arte de linha hipocrática que levantou a observação metódica contra a imaginação desordenada, a física contra a metafísica e o prodígio do comum contra os milagres de essência sobrenatural sempre lutou contra a ideia da origem diabólica ou divina dos males, e sempre agiu contra a sedimentação da doença como estigma. Entretanto, essa é uma luta constante, ainda não superada apesar do grande avanço da medicina científica e tecnológica, como analisa Susan Sontag em Doença como metáfora (1977), ao investigar a semelhança dos mecanismos de estigmatização de doenças epidêmicas e sem cura desde a antiguidade - lepra, sífilis, tuberculose - até a modernidade, quando um diagnóstico de câncer ou de Aids são tratados como uma sentença de morte de cunho obsceno: de mau agouro, lúgubre, abominável, repugnante aos sentidos, aos quais se deve associar um sentimento de vergonha e de culpa:

A persistência da ideia de que a doença revela e pune a frouxidão moral e a devassidão pode ser observada de outra maneira: verificando-se a constância das descrições da desordem ou da corrupção como uma doença. A metáfora da peste é tão indispensável quando se trata de julgar de modo sumário as crises sociais que sua utilização praticamente não diminuiu durante a era em que as doenças coletivas não eram mais abordadas de modo tão moralista (Sontag, 2007, p. 121).

Se isso é verdadeiro em relação à medicina moderna, tanto mais persiste nos rincões geográficos e culturais em que o entendimento dos sofrimentos físicos e mentais e de seus possíveis tratamentos ainda persistem solidamente inscritos numa concepção animista do mundo, da qual se originam os mitos. E um dos mitos que a ideia de um Brasil atrasado (e, portanto, doente, e, portanto, culpado, e, portanto, merecedor do sofrimento) veio sedimentando desde a modernidade foi o do fracassado, portador da patologia da ignorância sobre os avanços do mundo dito civilizado, e dos danos que o seu alijamento na partilha das 
conquistas econômicas e tecnológicas do ocidente viria a causar, comprometendo a saúde da nação.

Esse mito ganhou força simbólica na obra de Monteiro Lobato, através do personagem Jeca Tatu - do seu livro Urupês (1918), que contém histórias do trabalhador rural paulista, mas que acaba criando uma caricatura generalizada do matuto do interior -, cuja postura e comportamento diante da vida eram severamente condenados, quando submetidos à comparação com um modelo de "evolução" baseado na imagem do self-made man americano, alvo da admiração daquele grande modernista brasileiro. Inicialmente concebido para criticar a passividade do homem do campo, o Jeca ganha novos contornos durante as campanhas sanitaristas do início do século XX no Brasil, quando passa a ser utilizado pelo autor como arauto da esperança de redenção do brasileiro pela ciência médica. A "causa" da passividade do brasileiro do campo encontra finalmente uma explicação - a doença -, e uma esperança de cura pela educação, adoção de hábitos de higiene e mudança de hábitos alimentares. A imagem redimível ou redimida do caboclo - agora próspero, saudável e rico - passa, então, a circular em folhetins, e o "Jeca Tatuzinho" acaba se tornando o garoto propaganda do Almanaque Fontoura - financiado pelo medicamento que prometia a cura do "amarelão" (ancilostomíase), transmitido por ovos de parasitas depositados nas fezes, comum em regiões com precárias condições de saneamento, e responsável pelo estado anêmico que justificava a apatia do caboclo. A força do Jeca também foi comprovada pelo seu importante papel na popularização das campanhas de vacinação que tanta resistência produziram nos centros urbanos brasileiros na época.

A ciência do início do século XX e a ciência social institucionalizada no Brasil a partir dos anos 30 podem ser consideradas as linguagens, por excelência, do processo de construção nacional. Constitutiva da matriz dualista, a ciência buscava identificar os sintomas de nossa cultura, submetendo-os ao espelho crítico de um outro civilizado, resultando num instrumento do projeto modernizador que nos garantiria uma almejada sintonia com o progresso. Nísia Trindade Lima e Gilberto Hockman analisam como os textos dos higienistas das três primeiras décadas do século XX ultrapassaram os limites do debate sobre saúde e fomentaram representações mais amplas sobre a sociedade. No artigo "Pouca saúde, muita saúva, os males do Brasil são", eles se reportam especialmente à visibilidade do movimento pró- 
saneamento durante a Primeira República, com a construção de imagens fortes sobre o Brasil e os brasileiros, e à influência do diagnóstico sobre a nação feito pelos higienistas em textos literários e de divulgação. A imagem dominante de um Brasil doente mostra que

o movimento pelo saneamento teve um papel central e prolongado na reconstrução da identidade nacional a partir da identificação da doença como elemento distintivo da condição de ser brasileiro. [...] O Brasil foi pensado pelas suas ausências e o homem brasileiro como atrasado, indolente, doente e resistente aos projetos de mudança. [...] Questões como raça e herança colonial assumem crescente importância nas controvérsias que marcam as três últimas décadas do século XIX e as três primeiras décadas do século XX (Lima e Hochman, 2000, p. 314).

Para alguns intelectuais do período, "o traço negativo do brasileiro radicava-se na herança ibérica com sua tradição estadista e pouco propensa à iniciativa individual". Outros atribuíam o atraso à "composição étnica da população", em que predominavam mestiços e raças consideradas inferiores (Lima e Hochman, 2000, p. 314).

\section{O jeca como efígie nacional}

Apesar dos esforços da medicina e dos intelectuais progressistas como Monteiro Lobato no sentido de mitigar os sofrimentos do contingente populacional considerado "esquecido", a figura do Jeca Tatu original acabou se instaurando e consolidando uma imagem negativa não só do homem do campo, oriundo do interior de São Paulo, mas, sobretudo, do homem natural das regiões que não passaram por processos equivalentes de modernização e enriquecimento. A figurasíntese do habitante dessas regiões, em particular a região nordeste do Brasil, passa a ser a do sujeito detentor de uma condição mórbida constitucional. Ecoando a definição de Euclides da Cunha em Os Sertões (1902) - cujo bordão "O sertanejo é, antes de tudo, um forte" esbarra na definição de um personagem caquético e miserável (o "HérculesQuasímodo") -, o Jeca acaba contribuindo para a instauração de uma caricatura perversa, estabelecida a posteriori pelo monumental romance de 30 nordestino, cuja grandeza foi forjada, paradoxalmente, sobre a legitimização e popularização de um estigma, com graves consequências para a construção da identidade do homem do Nordeste.

Desde O Quinze (1930), de Rachel de Queiroz, passando por Vidas secas (1938), de Graciliano Ramos, até Morte e vida severina (1955), de 
João Cabral de Melo Neto, o intelectual nordestino, no afã de denunciar o seu pessimismo sobre as mazelas sociais da região, acaba varrendo qualquer crença na possibilidade de uma transformação positiva do Brasil por via da modernização. A essa crença não se soma, porém, nenhuma investigação sobre possíveis atenuantes, ou sobre valores intrínsecos desse povo e de seu modo de vida. O nordestino passa a ser definido apenas pelo que não é, como o primeiro Jeca Tatu de Lobato. À revelia, talvez, das intenções de seus autores, o romance de 30 se estabelece como uma literatura do ressentimento, que nada vê de positivo no sertanejo além de servir de fermento para a projeção nacional da cultura erudita que dele se alimenta.

Luís Bueno, em Uma história do romance de 30 (Bueno, 2006, p. 77) dedica um capítulo à análise da "figura-síntese" desta geração: o fracassado, mostrando como os modernistas de 22, em particular Mário de Andrade, citado como "o primeiro a apontar a recorrência dessa figura, para reprová-la" (Bueno, 2006, p. 74), criticaram a tendência derrotista que se instaurou na literatura brasileira com o romance regionalista, associada a uma ideia profundamente negativa de identidade nacional. Bueno se contrapõe à tendência de identificar nesse pessimismo o índice de uma "nacionalidade desarmada para viver", como sugere Mário de Andrade: ${ }^{2}$

Ao contrário, trata-se de uma nacionalidade que pretende mostrar sua força e seu aparelhamento para a vida ao encarar e incorporar o fracasso ao invés de escapulir para outros planos - para o plano que

\footnotetext{
${ }^{2}$ Em artigo escrito (em 28 de abril de 1940) para a coluna "Vida literária”, que mantinha no Diário de Notícias carioca, Mário de Andrade já alertava: "É estranho como está se fixando no romance nacional a figura do fracassado. Bem, entenda-se: pra que haja drama, romance, há sempre que estudar qualquer fracasso, um amor, uma terra, uma luta social, um ser que faliu. Mas o que está se sistematizando, em nossa literatura, como talvez péssimo sintoma psicológico nacional, absolutamente não é isso. Um D. Quixote fracassa, como fracassam Otelo e Mme. Bovary. Mas estes são seres dotados de ideais, de grandes ambições, de forças morais, intelectuais ou físicas. São, enfim, seres capacitados para se impor, conquistar, vencer na vida, mas que diante de forças mais transcendentes, sociais ou psicológicas, se esfacelam, se morrem na luta. E não estará exatamente nisto, neste fracasso, na luta contra forças imponderáveis e fatais, o maior elemento dramático da novela? Mas em nossa novelística o que está se fixando não é o fracasso proveniente de forças em luta, mas a descrição do ser incapacitado para viver, o indivíduo desfibrado, incompetente, que não opõe força pessoal nenhuma, nenhum elemento de caráter, contra as forças da vida, mas antes se entrega sem quê nem porquê à sua própria insolução. Será esta, por acaso, a profecia de uma nacionalidade desarmada para viver?” (Andrade apud Bueno, 2006, p. 75).
} 
os próprios romancistas de 30 chamariam de meramente estético, por exemplo (Bueno, 2006, p. 79). ${ }^{3}$

Além disso, ele assinala que o interesse pelo fracassado teria sido responsável pela incorporação das figuras marginais ao romance, o que considera "uma das maiores conquistas do romance de 30 para a ficção brasileira" (Bueno, 2006, p. 80). Bueno cita como exemplo dessa postura a literatura de Eça de Queirós,

para quem o debruçar sobre as desgraças do presente é uma forma de entreabrir as cortinas e vislumbrar o futuro. É exemplar, nesse sentido, o encerramento de $O$ crime do padre Amaro, em que o atraso português aparece contraposto ao avanço da França sacudida pela revolução e ao Portugal das conquistas marítimas cantado por Camões (Bueno, 2006, p. 78).

Esse "otimismo vicariante" de Bueno, porém, não é reconhecido nem mesmo pelos portugueses. Eduardo Lourenço, por exemplo, identifica na obra de Eça um "alegorismo-compensatório da generalizada consciência, entre a intelligentsia lusitana, de uma desvalia trágica, insuportável, da realidade nacional sob todos os planos" (Lourenço, 1991, p. 96), que ele identifica como obsessiva:

Nunca geração portuguesa se sentira tão infeliz - tão funda, sincera e equivocamente infeliz - por descobrir que pertencia a um povo decadente, marginalizado ou automarginalizado na História, e recebendo passivamente do movimento geral do que chamam extasiados A Civilização não só máquinas, artefatos, modas, mas sobretudo ideias... (Lourenço, 1991, p. 90).

\footnotetext{
${ }^{3}$ Diz Bueno que: “Em Mário de Andrade, o uso artístico da ‘língua brasileira’ extrapola em muito o mero questionamento de aspectos retrógrados da gramática tradicional, convertendo-se numa espécie de atualização radical de potencialidades da língua falada. E como os intelectuais de 30 vão avaliar esse procedimento? Não foi manifestação isolada a avaliação de Orris Barbosa em Momento, segundo a qual 'Macunaíma foi uma tentativa de romance nacional, em linguagem de experiência, empanturrada de símbolos complicados. Não pegou.' [...] E José Lins do Rego: ‘O movimento literário que se irradia do nordeste muito pouco teria que ver com o modernismo do sul. A língua que Mário de Andrade quis introduzir em Macunaíma é uma língua de fabricação; mais um arranjo de filólogo erudito do que um instrumento de comunicação oral ou escrito. O livro de Mário de Andrade só foi bem entendido por estetas, por eruditos, e o seu herói é tão pouco humano e tão artificial quanto o boníssimo Peri, de Alencar. Macunaíma é um Peri que se serviu da ruindade natural, em vez da bondade natural. Este livro é um repositório do folclore, o livro mais cerebral que já se escreveu entre nós'” (Bueno, 2006, p. 61).
} 
Ao contrário de Bueno, Lourenço não vê na mitificação desenvolvimentista da Geração de 70, incensada sobre a devastadora denúncia da pátria bisonha e atrasada, mais que um equívoco de jovens, reconhecido pelo próprio Eça em sua maturidade.

Médicos escritores modernos como Miguel Torga e Fernando Namora reforçarão em suas obras a percepção de particularismos da saúde do povo português segregado nas aldeias, e da beleza de sua forma de viver independente de comparações e analogias desenvolvimentistas - uma visão que ecoa os versos do pastor pessoano Alberto Caeiro: "Da minha aldeia vejo quanto da terra se pode ver do Universo/Por isso a minha aldeia é tão grande como outra terra qualquer,/Porque eu sou do tamanho do que vejo/E não do tamanho da minha altura" (Pessoa, 1969, p. 208). Ecoa ainda a reflexão de José Saramago (1995) sobre a fragilidade dos avanços modernos, que podem ruir a qualquer momento, devolvendo a humanidade às suas origens $\mathrm{e}$ atestando a cegueira do progresso indiscriminado, que vem sendo apontado como o único caminho para a "salvação" ocidental. Muito antes deles, porém, já se ouvia a indignada voz do camoniano Velho do Restelo aos navegadores portugueses:

E ponde na cobiça um freio duro,

E na ambição também, que indignamente

Tomais mil vezes, e no torpe e escuro

Vício da tirania infame e urgente;

Porque essas honras vãs, esse ouro puro,

Verdadeiro valor não dão à gente.

Melhor é merecê-los sem os ter,

Que possuí-los sem os merecer (Camões, 1962, p. 419).

Talvez venha daí a perspectiva antagônica que se percebe na tonalidade bem-humorada do ensaio de Mário de Andrade (similar à das recolhas de Michel Giacometti em Portugal) sobre a medicina excretícia no Brasil, quando comparada à ojeriza ao esterco humano contaminado por parasitas, tornado símbolo do movimento progressista alavancado por Monteiro Lobato. Enquanto este traduzia a visão de um Brasil doente, o outro insistia na imagem de um Brasil são, amparado no conceito do elemento lustral dos dejetos, seja pela "realidade fecundante do adubo", seja pelo "uso da refinação do açúcar com bosta de vaca":

Sem dúvida, não vou até afirmar que destas associações de imagens, o povo tire a inspiração primeira que o levou ao emprego medicinal dos excretos. Mas estes exemplos de sua vida cotidiana, esta manifestação 
objetiva do poder vivificador e purificador dos excretos, devem ter agido, a meu ver, na imaginação popular influenciável, como provas decisivas do valor terapêutico dos excretos, e contribuído para a conservação contemporânea da medicina excretícia (Andrade, 1972, p. 66).

\section{Macunaíma e a fábula da cigarra e da saúva}

Foi sobre essa percepção, portanto, que decidimos redigir este breve ensaio, no qual tencionamos mostrar a contribuição positiva dessas recolhas, no contexto da produção de seus autores, para a construção de leituras alternativas ao avassalador discurso desenvolvimentista herdeiro, talvez, do espírito das Conferências do Casino de 1871 em Portugal - que se alastrou no Brasil desde fins do século XIX. A perspectiva distanciada e irônica de Mário de Andrade sobre a hegemonia desse discurso acabou gerando uma saudável reação: a criação de um mito antagônico ao Jeca Tatu, o excêntrico e escrachado Macunaíma, "herói sem nenhum caráter", destinado a defender o direito do brasileiro de recusar a identidade jeca à qual parecia condenado pela intelectualidade da época. Como dizem Nísia Trindade Lima e Gilberto Hockman:

As visões sobre as mazelas do Brasil se dão dentro de um enquadramento dualista habitado por pares indissociáveis tais como litoral-sertão, saúde-doença e moderno-atrasado. [...] No caso brasileiro, a higiene, entre outros discursos de base científica, teve forte presença nas interpretações sobre os dilemas e as alternativas colocadas para a construção da nação. A ideia de males não apresenta, dessa forma, apenas uma analogia com o discurso médico, mas trata-se de uma alusão às doenças como obstáculo ao progresso ou à civilização (Lima e Hockman, 2000, p. 314-315).

É sabido que os modernistas da Semana de Arte de 1922 hostilizaram Lobato por várias razões, criando mesmo um mal-estar que contribuiu para a sua "demonização" no cenário intelectual da época, o que não fez justiça à imensa contribuição desse autor para o melhoramento do país em várias frentes. Entretanto, numa perspectiva um tanto isolada e inusitada, Mário de Andrade parecia perceber a natureza perversa e mesmo deletéria da imagem do Jeca Tatu, se alçado soberanamente a efígie do Brasil. Cremos que foi em resposta a esse incômodo que ele buscou engendrar um outro mito, fundado em suas sólidas pesquisas sobre as origens dos nativos destas terras e de outras que para ela migraram, e na valorização de seus modos de ser específicos, ainda não contaminados pelo ressentimento de 
"não-ser" (europeu ou norte-americano) que acometia Lobato. ${ }^{4}$ Macunaíma (1928) afigura-se uma resposta alegre e bem documentada ao Jeca Tatu, funcionando como um arauto talvez mais realista e promissor da esperança no futuro da pátria do que o personagem de Lobato, e numa correção dos excessos da visão desenvolvimentista do próprio Lobato - cujos trejeitos eivados de provincianismo o arrogante e híbrido Macunaíma chega a cacoetar em algumas passagens da novela.

A preguiça parece ser o elemento dialógico mais importante entre Jeca e Macunaíma. Enquanto é atacada e condenada como vício no primeiro, passa a ser apreciada e exaltada no segundo. A tradução de Makunaíma, na Venezuela e na Guiana, de onde veio a lenda original, é o "Grande Mau". O nome dessa entidade era tão potente que os missionários jesuítas usaram-no para traduzir o nome de Deus para os índios. Era o "Grande Mau", poderoso e transformador, que ressuscitava os mortos. O personagem brasileiro, porém, estaria mais para um "Pequeno Mau", um entrave à lógica do mundo moderno, fincadas as raízes de seu entendimento e de sua conduta noutra lógica, mais afeita à do homem do campo, do índio e do negro iletrados, porém espertos, donos de uma sabedoria cada vez mais inapreensível pelo Brasil urbano, erudito e civilizado que se anunciava no início do século XX. Uma sabedoria lânguida, divertida, matreira e resistente; sobrevivente, mesmo, que evoca a antiga fábula da cigarra e da formiga para valorizar o ócio em lugar do negócio, o prazer em detrimento do trabalho, a alegria sobre a obrigação. Daí a frase característica do personagem: "Ai, que preguiça!". Como na língua indígena o som "aique" significa "preguiça", Macunaíma seria duplamente preguiçoso. Não por acaso, a imagem da formiga é um importante topos nesse livro,

\footnotetext{
${ }^{4}$ Esse ressentimento provincianista atribuído a Monteiro Lobato é bem percebido no trecho do conto "Jeca Tatuzinho", veiculado no Almanaque Fontoura, que descreve a transformação do caboclo após o tratamento médico: "Em pouco tempo, os resultados foram maravilhosos. Jeca adquiriu um caminhão Ford, e em vez de conduzir os porcos ao mercado pelo sistema antigo, levava-os de auto, num instantinho, buzinando pela estrada afora, fon-fon! fon-fon!... As estradas eram péssimas; mas ele consertou-as à sua custa. Jeca parecia um doido. Só pensava em melhoramentos, progressos, coisas americanas. Aprendeu logo a ler, encheu a casa de livros e por fim tomou um professor de inglês. Quero falar a língua dos bifes para ir aos Estados Unidos ver como é lá a coisa. O seu professor dizia: O Jeca só fala inglês agora. Não diz porco; é pig. Não diz galinha! É hen... Jeca só fumava charutos fabricados especialmente para ele, e só corria as roças montado em cavalos árabes de puro sangue. Quem o viu e quem o vê! Nem parece o mesmo. Está um "estranja” legítimo, até na fala” (Lobato, 1924).
} 
dialogando com a imagem do caboclo apático e doente da obra de Lobato, retratado como vítima dos insetos:

Jeca só queria beber pinga e espichar-se ao sol no terreiro. Ali ficava horas, com o cachorrinho rente; cochilando. A vida que rodasse, o mato que crescesse na roça, a casa que caísse. Jeca não queria saber de nada. Trabalhar não era com ele. Perto morava um italiano já bastante arranjado, mas que ainda assim trabalhava o dia inteiro. Por que Jeca não fazia o mesmo?

Quando lhe perguntavam isso, ele dizia:

- Não paga a pena plantar. A formiga come tudo.

- Mas como é que o seu vizinho italiano não tem formiga no sítio?

- É que ele mata.

- E por que você não faz o mesmo?

Jeca coçava a cabeça, cuspia por entre os dentes e vinha sempre com a mesma história:

- Quá! Não paga a pena...

- Além de preguiçoso, bêbado; e além de bêbado, idiota, era o que todos diziam (Lobato, 1951, p. 329-331).

Ao contrário do Jeca Tatu de Lobato, do Juca Mulato de Menotti del Picchia e de outros personagens semelhantes, o Macunaíma de Mário de Andrade não parece encarnar uma praga nacional, mas algo diferente. Sua preguiça é alvo de uma atenção particularizada e não submetida à avaliação comparativa e valorativa com o modelo ideológico e econômico estrangeiro, europeu ou norte-americano, como nos demais exemplos criados pelos modernistas de então, em franca campanha contra a idealização romântica do indígena e do caboclo. O movimento higienista dos anos 1920, na contracorrente do movimento indigenista romântico, revelou um Brasil desconhecido para os brasileiros da cidade, trazendo a informação de que, mesmo os sertões mais saudáveis do Nordeste e do Sul eram "verdadeiros matadouros", quando ainda se supunha que os sertões brasileiros eram sanatórios miraculosos, a cujos ares nem a própria tuberculose resistia.

Em plena atmosfera de entusiasmo pela ciência - no diálogo que os cientistas e médicos sanitaristas travam em fins da década de 1910 com as interpretações ufanista e romântica sobre a natureza e o homem brasileiros, momento em que ganha destaque a ideia do sertão como sinônimo de doença e, também, de uma natureza agressiva ao homem - ${ }^{5}$

\footnotetext{
${ }^{5}$ Apesar do discurso desenvolvimentista, Lobato reflete uma perspectiva ecologicamente correta ao descrever, na revista Saúde, órgão da Liga Pró-Saneamento do Brasil, as razões do adoecimento do
} 
Mário de Andrade toca uma nota dissonante em seu romance. Nele, a saúva aparece como um símbolo ambíguo: menos percebida como praga da agricultura, cujo papel "anticivilizatório" adviria de sua ação efetivamente deletéria no campo, destruindo as plantações e causando prejuízos, ela é identificada como um "inseto operário" que se confunde com o próprio trabalhador incansável sempre a postos, metáfora do empreendedorismo e do desenvolvimento, e antípoda da cigarra, portanto, irresponsável e afeita à preguiça, à passividade e à diversão. ${ }^{6}$

Talvez por isso também seja ambíguo o dístico com que o "Imperador Macunaíma" conclui o parágrafo de sua famosa "Carta pras Icamiabas", onde dá notícias ao povo indígena das contradições que encontra na grande cidade de São Paulo, particularmente no trecho em que avalia as condições de saúde dessa população:

Porém, senhoras minhas! Inda tanto nos sobra, por este grandioso país, de doenças e insetos por cuidar! [...] Tudo vai num descalabro sem comedimento, estamos corroídos pelo morbo e pelos miriápodes! Em breve seremos novamente uma colônia da Inglaterra ou da América do Norte!... Por isso e para eterna lembrança destes paulistas, que são a única gente útil do país, e por isso chamados de Locomotivas, nos demos ao trabalho de metrificarmos um dístico, em que se encerram os segredos de tanta desgraça: "Pouca saúde e muita saúva, os males do Brasil são" (Andrade, 1978[1927], p. 105). ${ }^{7}$

homem brasileiro: "Por que degenera ele justamente onde por impulsão ambiente, deveria altear-se ao apogeu? Por que na Amazônia, onde tudo alcança o máximo, só ele dá de si o mínimo? E como resposta: O homem com o civilizar-se, afastou-se da natureza. Desrespeitou-a, infringiu-lhe as leis. A consequência disso foi o enfraquecimento” (Lobato apud Lima e Hochman, 2000, p. 318).

${ }^{6}$ Como diz Sérgio Buarque de Holanda, em Raízes do Brasil: "Podemos construir obras excelentes, enriquecer nossa humanidade de aspectos novos e imprevistos, elevar à perfeição o tipo de civilização que representamos: o certo é que todo o fruto de nosso trabalho ou de nossa preguiça parece participar de um sistema de evolução próprio de outro clima e de outra paisagem” (Holanda, 2004, p. 31).

${ }^{7}$ Com essa frase, "Macunaíma” assinou o livro de visitas do Instituto Butantan, o orgulho dos paulistas - o slogan recupera conhecido poema de Gregório de Matos (1636-1695), em que o poeta satírico baiano enumera as vilezas do país, terminando cada estrofe com o irônico refrão: "Milagres do Brasil são" (Matos, 2002, p. 45). Remete, também, à frase do cronista Saint-Hilaire: “Ou o Brasil acaba com a saúva ou a saúva acaba com o Brasil”. A história do Instituto Butantan confunde-se com a história da modernização do Estado de São Paulo. Seu surgimento deveu-se a uma epidemia de peste bubônica no Porto de Santos. Seu diretor, Adolfo Lutz, mandou para essa cidade o assistente Vital Brazil, que em pouco tempo diagnosticou a doença e, em conjunto com o médico Osvaldo Cruz, criou um plano para controlá-la. Entretanto, devido principalmente à expansão da cafeicultura, os trabalhadores rurais viam-se frequentemente submetidos a acidentes ofídicos. As serpentes venenosas transformavam-se em um grande problema que, juntamente com a peste bubônica, atentava contra o desenvolvimento paulista. Vital Brazil, a par de toda essa 
Num sentido literal, as formigas devoradoras das culturas agrícolas seriam equivalentes aos demais insetos e "lacraias" que infestariam o país, favorecendo a transmissão de doenças e dificultando o progresso da nação. Num sentido figurado, porém, as "saúvas" seriam sinônimo das mesmas "locomotivas" - os paulistas, "única gente útil do país" -, ironicamente tomados, aqui, como determinantes dos males do "Brasil são" (onde o verbo passa a ser lido como adjetivo): o Brasil até então saudável, o Brasil das Icamiabas e do próprio Macunaíma, que já não pode se reconhecer em sua própria terra sem ter de apelar para os trejeitos estrangeiros, expressos na linguagem pernóstica e hipócrita que passa a adotar para falar com a sua tribo. A carta satiriza os beletristas parnasianos, tão comuns na época, e os academicismos e pedantismos da língua escrita e da dicção culta de origem lusitana, vaidades às quais o próprio narrador da missiva, o "Imperador", parece vulnerável. ${ }^{8}$

Esta demarcação linguística, menos do que corroborar o impulso antilusitanista dos primeiros modernistas brasileiros - como costuma ser interpretada -, teria talvez o objetivo de acentuar deliberadamente a inevitável distância entre o intelectual e o cidadão comum, e de explicitar a consciência de Mário de Andrade, nem sempre partilhada pelos seus pares, da impossibilidade de "falar pelo povo", apesar do seu desejo de falar "em defesa deste povo". Essa consciência só encontraria eco na intelectualidade brasileira muito mais tarde, nas obras de autores como Guimarães Rosa, Osman Lins e Clarice Lispector. Guimarães Rosa, por exemplo, com o seu fulgurante "Ser-tão" diadorínico (1956) - deliberada mais-valoração do sertanejo na literatura -, encontra a vereda de um feminino que se insinua leve, poético, lírico, derramando um olhar

problemática, concomitantemente aos estudos sobre a peste, iniciou as suas pesquisas sobre o ofidismo, tema então pouquíssimo conhecido. O extenso trabalho que desenvolveu pesquisando esse assunto fez com que o Butantan rapidamente se especializasse no conhecimento herpetológico, bem como na produção de soros antiofídicos, tornando-se uma entidade ímpar em todo o mundo. Posta no livro do instituto especializado no tratamento de venenos e peçonhas, a frase de Mário de Andrade teria reforçado o seu duplo sentido.

${ }^{8}$ Não só o “Imperador” das Icamiabas se confessa vulnerável a esta vaidade, mas o próprio autor, com a sua consciência artística agudíssima, admite deliberadamente que "forçou a nota" em Macunaíma, conforme o condenavam os críticos da época - "acusação" que ele assume como um elogio: "Essa censura que o senhor me faz de ter uma língua que não é de ninguém, mas "artificial”, é perfeitamente justa sob o ponto de vista da arte como da ciência da linguagem” (Andrade apud Bueno, 2006, p. 61, nota de rodapé 24). Observe-se que Mário de Andrade não identifica o elemento colonizador com o português, mas prefere unificar todos os falantes da língua portuguesa sob uma mesma ameaça: a de sucumbirem, novamente, ao domínio da Inglaterra ou da América do Norte. 
indiscutivelmente verde e fecundante sobre a paisagem devastada, fingindo ser homem, marrom e cangaceiro apenas para ludibriar a tirania do "gênero Rio-baldo" (ou regionalista) e de seu "pacto Hermo-gênico" (ou demoníaco) com a mentalidade crítica brasileira de seu tempo. Feminino que Osman Lins recupera na figura da miserável Maria de França, personagem da escritora nordestina Júlia Marquezim Enone, inédita e parafraseada postumamente pelo seu biógrafo, autor do romance A rainha dos cárceres da Grécia (1976), e que Clarice Lispector corrobora na figura da pobre Macabéa, personagem de $A$ hora da estrela (1977), cujo silêncio contribui para denunciar a apropriação que o escritor Rodrigo S. M. faz de sua desgraça em benefício próprio.

A descaracterização da cultura popular, portanto, e a força de constrangimento social da cultura dominante, inapreensível pelo povo, parece ser o mote do romance de Mário de Andrade, que inverte o sentido das cartas dos cronistas coloniais, que escreviam a Portugal para narrar suas descobertas e dar contas dos resultados dos investimentos da Coroa nas navegações. A "Carta pras Icamiabas", ao contrário, é cinicamente endereçada às índias pelo seu rei, como pretexto para extorquir dinheiro de suas súditas, revelando o processo de aculturamento do índio na cidade grande e sua degeneração moral, que é entendida como parte de uma enfermidade adquirida pelo contato do nativo com o meio urbano e com seus valores distorcidos.

\section{Conclusão}

Em O que é medicina popular, Elda Rizzo de Oliveira comenta que não existe um modo único, original e ideal, válido para todas as pessoas e classes sociais, de criar suas estratégias de vida, inclusive as de cura. Nos grupamentos civilizados, onde passa a imperar a medicina acadêmica e erudita - com seus hospitais e laboratórios dotados de tecnologias sofisticadas, com seus agentes formados e medicamentos industrializados -, a medicina popular torna-se uma alternativa a ser vivida, ilegalmente, apenas pelas populações pobres, analfabetas, que moram nas regiões do interior do Brasil, e que, por ignorância, dispõem de recursos precários ministrados por seus agentes, pejorativamente identificados como "charlatães": garrafadas, chás, benzimentos, rezas, banhos, massagens 
etc.; os quais, por carecerem de fundamento científico, são considerados "imposturas" - quando não crimes passíveis de pena. ${ }^{9}$

Previsto pelo Código Penal Brasileiro, o "curandeirismo" - ou "a prática de prescrever, ministrar ou aplicar habitualmente qualquer substância, bem como usar gestos, palavras ou qualquer outro meio para fazer diagnósticos ou promover a cura sem habilitação médica" (Brasil, 1940, artigo 284) - desautoriza não só os agentes populares da saúde, como também rejeita seus hábitos e saberes muitas vezes antigos, herdeiros de diferentes traços culturais (mágicos, indígenas, africanos, ibéricos), nem sempre utilizados com os propósitos e o entendimento da medicina moderna - cujo principal objetivo é suprimir os sintomas e curar as desordens orgânicas para devolver o sujeito à linha de produção. A saúde, como qualquer mercadoria, é considerada um "bem" nas sociedades modernas, a ser rapidamente restituído ao sujeito que precisa voltar ao mercado de trabalho.

Nas sociedades arcaicas ou rurais, porém, a experiência da dor e do sofrimento é vivida de outra maneira, numa comunidade acolhedora que partilha as necessidades e aflições dos indivíduos através de uma vivência comunitária e solidária, concebida como um prolongamento da vida no campo, e movida por formas específicas de atuação, utilidade e validade. Segundo Elda Rizzo de Oliveira:

Estas medicinas são afirmadoras e recriadoras da cultura popular. Veiculam diferentes sistemas de classificação de doenças e de fenômenos orgânicos, e produzem estratégias de cura muito específicas, pautadas por uma prevenção, um diagnóstico e um enfrentamento significativos apenas como parte da compreensão que seus sujeitos têm da vida, do mundo, das necessidades, dos valores e das relações sociais. São parte de sua visão de mundo, permanentemente recriada e reinventada (Oliveira, 1985, p. 32).

\footnotetext{
${ }^{9}$ Em “Introdução ao estudo da história da medicina popular no Brasil”, Pedro Nava alerta: "Dentro do sem-número de charlatães e de curiosos que no nosso interior e nas nossas cidades concorrem com o médico, é preciso distinguir o espertalhão, o contraventor, o explorador da ingenuidade e da crendice do povo - da figura mais complexa do curandeiro que exerce por uma espécie de gosto inato, de tendência e de vocação. Se o primeiro só cuida de aguçar a sua capacidade para o engano e o dolo, o segundo consegue muitas vezes uma prática que não é para desprezar numa terra onde vastas zonas do interior não contam com qualquer assistência médica governamental ou civil. O gosto do povo concorre também para o aparecimento destes tipos que lhe são muito mais próximos e acessíveis que o profissional, cujos serviços têm preços que os transformam em mercadoria proibida para o grosso de nossa população” (Nava, 2003, p. 207).
} 
A curiosa ambiguidade do dístico de Mário de Andrade no livro Macunaíma nos leva a pensar sobre a percepção que o escritor traduzia sobre o duplo desafio do Brasil naquelas primeiras décadas do século XX: o de se modernizar, absorvendo a inspiração das "formigas" diligentes, mas mantendo o respeito à cultura já existente e à realidade do país em sua extensão e diversidade. Seria isso o que o levaria, talvez, a desconfiar do excesso de "diligência" dessas mesmas formigas, tomadas como representantes simbólicas da modernidade e de suas contradições. Por essa razão, Macunaíma talvez possa ser lido como uma crítica satírica à condenação dos modernistas do brasileiro "típico", definido por sua miscigenação e indolência - condições tidas como responsáveis pela "patologia do subdesenvolvimento". Na ótica de Mário de Andrade, a sensualidade e o aspecto lúdico do "brincar" figuram entre as principais qualidades desse povo - em outros contextos repudiado justamente por suas características inatas, desmerecidas quando da comparação com modelos estrangeiros. Isso faria de Macunaíma uma alegoria sobre a identidade nacional em que a fábula da preguiça adquire uma expressão positiva e heroica - não por incensar a inatividade, afundar na insalubridade e entregar-se à implacabilidade do destino -, mas por reativar uma memória supostamente original de um brasileiro nativo em harmonia com a natureza e ignorante das mazelas e angústias de um sistema econômico alheio às suas ambições, e de uma filosofia de vida cujo sentido lhe escapa.

Em O normal e o patológico, Georges Canguilhem define como "doença do homem normal" o distúrbio que, com o tempo, "se origina da permanência do estado normal, da uniformidade incorruptível do normal, a doença que nasce da privação de doenças, de uma existência quase incompatível com a doença" (Canguilhem, 2010, p. 246). O ser humano privilegiado por uma experiência de bem-estar resultante de seu acesso a boas condições de vida: moradia, alimentação, vacinação, esportes, lazer etc. - consequência do desenvolvimento econômico e das conquistas da ciência sobre a natureza - só sabe que é "normal" quando percebe que nem todas as pessoas são como ele e, por conseguinte, reflete que é capaz de ficar doente, assim como "apenas o ignorante pode se tornar sábio".

Esse convívio da parcela favorecida da sociedade com a diversidade de condições de que padece o resto da humanidade gera uma insegurança nesses indivíduos, determinando uma nova "patologia". 
Canguilhem afirma que "a doença do homem normal é o aparecimento de uma falha na sua confiança biológica em si mesmo" (Canguilhem, 2000, p. 245). É essa desconfiança, contudo, que pode despertar a sua consciência e sensibilidade para uma realidade que o transcende. Segundo a medicina popular - nascida no seio das culturas mais vulneráveis às agressões naturais, e, portanto, mais habituadas ao exercício da solidariedade diante de um mundo ameaçador e adverso -, essa desconfiança pode mesmo ser considerada uma manifestação de saúde, num sentido mais amplo do que aquele avaliado apenas pelas condições de higidez orgânica e fisiológica. Refletindo esse amadurecimento, a literatura contemporânea de língua portuguesa, em seus melhores expoentes, parece tender a uma reinvenção promissora e salutar quando - em lugar de condenar a nossa suposta danação à identidade jeca ou valer-se dela para rechaçá-la - prefere optar por invocar a beleza e a força deste "povo que falta".

\section{Referências}

ANDRADE, Mário (1978). Macunaíma, o herói sem nenhum caráter. Edição crítica de Telê Porto Ancona Lopez. Rio de Janeiro: Livros Técnicos e Científicos.

(1972). Namoros com a medicina. São Paulo: Martins.

(1993). A divina preguiça. In: Vida literária. Edição de Sonia Sachs. São Paulo: Hucitec, EDUSP.

BRASIL (1940). Código Penal. Disponível em: <http://www.planalto.gov.br/ccivil_03/decreto-lei/del2848.htm>. Acesso em: 10 mar. 2014.

BUENO, Luis (2006). Uma história do romance de 30. São Paulo: EDUSP; Campinas: Unicamp.

CAMÕES, Luís de (1962). Os Lusíadas. São Paulo: Melhoramentos.

CANGUILHEM, Georges (2010). O normal e o patológico. Rio de Janeiro: Forense Universitária.

CUNHA, Euclides da (1985). Os sertões. Rio de Janeiro: Tecnoprint.

DELEUZE, Gilles (2008). A literatura e a vida. In: Crítica e clínica. São Paulo: Editora 34. 
GIACOMETTI, Michel. Artes de cura e espanta-males. Espólio de Medicina Popular recolhido por Michel Giacometti. Organização de Ana Gomes de Almeida, Ana Paula Guimarães e Miguel Magalhães. Lisboa: Gradiva, 2010.

HOLANDA, Sérgio Buarque de (2004). Raízes do Brasil. São Paulo: Companhia das Letras.

LIMA, Nísia Trindade; HOCKMAN, Gilberto (2000). Pouca saúde, muita saúva, os males do Brasil são... Discurso médico-sanitário e interpretação do país. Ciência E saúde coletiva, v. 5, n. 2, p. 313-332. Disponível em: <http://www.scielo.br/pdf/csc/v5n2/7098>. Acesso em: 10 fev. 2014.

LINS, Osman (1976). A rainha dos cárceres da Grécia. São Paulo: Melhoramentos.

LISPECTOR, Clarice (1977). A hora da estrela. Rio de Janeiro: Rocco.

LOBATO, Monteiro (1924). Jeca Tatuzinho. Disponível em: <http://lobato.globo.com/misc_jeca.asp>. Acesso em: 10 mar. 2014

Brasiliense.

(1951). Urupês. In: Obras completas de Monteiro Lobato. v. 1. São Paulo:

LOURENÇO, Eduardo (1991). Da literatura como interpretação de Portugal. In: O labirinto da saudade. Lisboa: Dom Quixote.

NAVA, Pedro (2003). Capítulos da história da medicina no Brasil. São Paulo: Ateliê.

NETO, João Cabral de Melo (1978). Morte e vida Severina e outros poemas em voz alta. Rio de Janeiro: José Olympio.

OLIVEIRA, Elda Rizzo de (1985). O que é medicina popular. São Paulo: Abril Cultural; Brasiliense.

PESSOA, Fernando (1969). Obra poética. Rio de Janeiro: Nova Aguilar.

QUEIROZ, Rachel de (2005). O Quinze. São Paulo: José Olympio.

RAMOS, Graciliano (1977). Vidas secas. Rio de Janeiro: Record.

ROSA, Guimarães (2004). Grande sertão: veredas. Rio de Janeiro: Nova Fronteira.

SARAMAGO, José (1995). Ensaio sobre a cegueira. São Paulo: Companhia das Letras.

SONTAG, Susan (1997). Doença como metáfora. São Paulo: Companhia das Letras.

Recebido em julho de 2013.

Aprovado em dezembro de 2013. 


\section{resumolabstract}

\section{Os males do Brasil são: a doença como elemento distintivo da condição de ser brasileiro}

Ermelinda Maria Araújo Ferreira

Este ensaio nasceu da intenção de comparar as recolhas de dados sobre a medicina empírico-tradicional em Portugal e no Brasil, por iniciativa de Michel Giacometti, naturalizado português, cujo acervo, recentemente descoberto, foi reunido no volume Artes de Cura e Espanta-Males (2009), e do brasileiro Mário de Andrade, autor do livro Namoros com a Medicina (1937). A similaridade desses trabalhos aponta para o interesse desses pesquisadores sobre a cultura popular - em particular aquela relacionada ao entendimento espontâneo do povo lusobrasileiro sobre os males do corpo e da alma, e de suas interpretações metafóricas e estigmatizantes sobre a doença como um mal social. A partir daí, pretendeu-se tecer uma análise sobre a construção e desconstrução de mitos identitários brasileiros como Jeca Tatu e Macunaíma, analisando seus antecedentes no imaginário literário português e suas repercussões na moderna literatura nacional.

Palavras-chave: identidade nacional, literatura e regionalismo, medicina popular, Mário de Andrade, Michel Giacometti.

\section{"Os males do Brasil são": the disease as a distinctive feature of the condition to be Brazilian}

Ermelinda Maria Araújo Ferreira

This essay was born of the intention to compare the data collections on the empirical-traditional medicine in Portugal and Brazil, on the initiative of Michel Giacometti, naturalized Portuguese, whose work, recently discovered, was collected in the volume Artes de Cura e Espanta-Males (2009), and the Brazilian writer Mário de Andrade, author of Namoros com a Medicina (1937). The similarity of these works points to the interest of these researchers on popular culture - in particular that related to the spontaneous understanding of the lusobrazilian people about the evils of body and soul, and its stigmatizing and metaphorical interpretations of illness as a social evil. From there, it was intended to make an analysis of the construction and deconstruction of Brazilian identity myths as Jeca Tatu and Macunaíma, analyzing their background in Portuguese literary imagination and its impact on modern Brazilian literature.

Keywords: national identity, literature and regionalism, popular medicine, Mário de Andrade, Michel Giacometti. 